\title{
A Review Paper on Remedies to the Common Deficiencies Faced in Mivan Technology
}

\author{
Prof. R. B. Bajare*, Shubham Deshmukh ${ }^{1}$, Ashwin Mahajan ${ }^{2}$, \\ Roohi Karnataki ${ }^{3}$, Indrayani V. Patil ${ }^{4}$. \\ (Prof., Civil Department, Sinhgad Academy of Engineering, Kondhwa, Pune, Maharashtra) \\ ${ }_{1,2,3,4}$ (Students, Civil Department, Sinhgad Academy of Engineering, Kondhwa, Pune, Maharashtra)
}

\begin{abstract}
Mivan Technology is latest trend followed by developing and developed countries for mass housing projects. India being a developing country and shortage of houses for poor, this technology is nowadays widely used for government housing schemes and also by private construction companies. Mivan technology gives monolithic cellular structure with most minimum weight and the post failure damages get reduced considerably. In this review paper we have studied the problem like Honey-combing, Cracks due to shrinkage of concrete and segregation. To tackle these deficiencies, improvements in characteristic in concrete for reducing the problems faced in constructions by using aluminium formwork or Mivan Technology.
\end{abstract}

Keywords: Aluminium Formwork, Mivan Technology, Honey-combing, Cracks.

\section{Introduction}

The system of aluminum formwork (MIVAN) has been used widely in the construction of residential units and mass housing projects. It is fast, simple, adaptable and cost - effective. It produces total quality work which requires minimum maintenance and when durability is the prime consideration. This system is most suitable for Indian condition as a tailor-made aluminum formwork for cast-in-situ fully concrete structure. In this system of formwork construction, cast - in - situ concrete wall and floor slabs cast monolithic provides the structural system in one continuous pour. Large room sized forms for walls and floors slabs are erected at site. These forms are made strong and sturdy, fabricated with accuracy and easy to handle. They can be used repeatedly for approximately 250 times. The concrete is produced in RMC batching plants under strict quality control and convey it to site with transit mixers.

The frames for windows and door as well as ducts for services are placed in the form before concreting. Staircase flights, elevation panels, chajjas and jails etc. and other pre-fabricated items are also integrated into the structure. This proves to be a major advantage as compared to other modern construction techniques. The method of construction adopted is no difference except for that the sub - structure is constructed using conventional techniques. The super-structure is constructed using MIVAN techniques. The integrated use the technology results in a durable structure.

Due to complexity of reinforcement and less thickness of wall, problems of honeycombing and shear cracks due to mass concreting are observed on various sites. Therefore these problems needs to be tackled in effective way to ensure quality and safety of structure. These problems can be reduced by improving concrete characteristics.

\section{Literature review}

1) Emerging Trends in Formwork - Cost Analysis \& Effectiveness of Mivan Formwork over the Conventional Formwork-By Miss. Patil Dhanashri Suryakant, Prof. Desai D B.

This is the case study of Godrej garden enclave which is constructed by using MIVAN technology by construction division of Godrej and Boyce Mfg. Co. Ltd Vikhroli, Mumbai. This paper is based on detailed cost saving analysis for Mivan formwork over the wooden (conventional) formwork. It has also given the details of components of Mivan formwork.

2) Comparative study of formwork in building construction.- By Dr. M. N. Bajad, Pawan S. Khandelwal, Avihv Vyavhare.

This paper is comparative study and case study of Sayantara residential building in Ahmednagar. This building is based on conventional formwork construction. This study is based on parameters like concrete, steel, wall, formwork, labor etc. India, being the second largest urban populated nation in the world, there is an increase in demand for housing in India. Thus high rise buildings are gaining popularity. Aluminium formwork system is successfully used in Japan, Singapore, Malaysia and Middle East countries. It has significant advantages over conventional techniques such as speed, strength and cost saving on mass construction. 
3) Cost Effective House by Using Various Construction Techniques and Materials.- By Prof. U. J. Phata, Prof. C. S. Chavan, Lalit V. Rathod, Vishwas L. Nachare, Atul, B. Suryawanshi.

It is a comparison of different construction techniques used for low cost housing. The compared techniques are 1. Rat-trap bond technology, 2. Filler slab technology, 3. Aluform technology (Mivan technology), 4. Gypsum area separation wall. The study is based on literature survey and field survey.

\section{4) Mivan Technology.- By Mr. Shankar Bimal Banerjee, Mr. Pawan Dilip Barhate, Mr. Vipul Pradip} Jaiswal.

This paper tries to give brief introduction to the readers, regarding the mivan technology, it is a precisionengineered formwork fabricated in Aluminium and how the uses of mivan, can save time and money for a multcrore project.

\section{5) Comparative Studies of Construction Techniques (Conventional Technique Vs Aluminium Formwork Techniques)- By Umang Patel, Bhupendra M Marvadi, Ninjal M. Parekh.}

The paper discusses the importance and scope of recent trends in construction techniques. The paper emphasizes on exploitation differing kinds of materials in modern trends and for effectiveness in infrastructure building for fast economic process and development of a nation exploitation recent advancements within the field of construction technology. Nowadays, the prefabrication and aluminium formwork technique in trade construction industry is developed countries has improved the standard of the construction industry. Aluminium Formwork System is a construction system for forming cast in situ concrete structure of a building. Classified information's given for Aluminium Formwork technique and Conventional techniques. Two case studies are taken for the analysis of the construction techniques. The concept of formed (also called "prefabricated") construction includes those buildings wherever the bulk of structural parts are standardized and created in plants during a location far from the building, so transported to the location for assembly.

\section{PROBLEM STATEMENT}

1) Cracks due to shrinkage of concrete are likely to appear.

2) Due to less thickness of wall honey-combing is commonly seen problem.

3) Due to complexity and high density of reinforcement at corners segregation occurs.

\section{OBJECTIVES}

1) To increase workability over long period for mass concreting work.

2) To increase compressive strength of concrete.

3) To reduce cracks due to shrinkage of concrete.

4) To reduce segregation and honey-combing effect at joints where dense reinforcement is provided.

\section{Methodology}

1) Literature survey on the modern construction techniques used.

2) Site visit and identification of problems such as cracks, honey-combing, segregation.

3) Possible remedies for identified problem by improving concrete characteristics.

4) Various tests on concrete.

5) Graphical and analytical Presentation of test data.

\section{Expected conclusion}

1) Reduction in honeycombing.

2) Reduction in cracks

3) Improvement in surface finishing and overall quality of structure.

4) Improvement in strength of structure.

5) Increased resistance to weathering action due to less or no honeycombing.

\section{References}

[1]. Miss. Patil Dhanashri Suryakant , Prof. Desai D B "EMERging Trends in FormwOrk - Cost Analysis \& EFFECTIVEness OF MIVAN FORMWORK OVER THE CONVENTIONAL FORMWORK" (IOSR JOURNAL OF MECHANICAL AND CIVIL ENGINEERING (IOSRJMCE) ISSN: 2278-1684, PP: 27-30 WWW.IOSRJOURNALS.ORG)

[2]. Dr. M. N. Bajad, Pawan S. Khandelwal, Avihv Vyavhare. "Comparative study of formwork" (ijoer, vol. 4., issue.32016 may-june) issn: 2321-7758 building construction)

[3]. Prof. C. S. Chavan, Lalit V. Rathod, Vishwas L. Nachare, Atul, B. Suryawanshi. "Cost Effective House by Using Various Construction Techniques and Materials"(IJOAR Volume : 4 | Issue : 4 | Apr 2014 | ISSN - 2249-555X)

[4]. Mr. Shankar Bimal Banerjee, Mr. Pawan Dilip Barhate, Mr. Vipul Pradip Jaiswal. "Mivan Technology"(.International journal of innovations in engineering research and technology [ijiert] Issn: 2394-3696 Volume 2, issue 3 march2015) 
[5]. Umang Patel, Bhupendra M Marvadi, Ninjal M. Parekh. "Comparative Studies of Construction Techniques (Conventional Technique Vs Aluminium Formwork Techniques) ISSN: 0975 - 6744| NOV 14 TO OCT 15 | Volume 3, Issue 2

[6]. Prof. U. J. Phatak Prof.C.S.Chavan, Lalit V. Rathod. "Cost Effective House by Using Various Construction Techniques and Materials”(IJOAR Volume : 4 | Issue : 4 | Apr 2014| ISSN - 2249-555X)

[7]. Divyang Solanki, Rinni Shah, Noopur Shah. "Benefits of Mascon Construction System in Economical Area"(IJSRD - International Journal for Scientific Research \& Development| Vol. 1, Issue 3, 2013 | ISSN (online): 2321-0613)

[8]. Rohan D More, Dr. Y. S. Patil. "Comparative Analysis with Mivan Formwork \& Concrewall Structure". International Journal of Current Trends in Engineering \& Research (IJCTER) (e-ISSN 2455-1392 Volume 2 Issue 2, February 2016 pp. 132 - 135)

[9]. http://www.architectjaved.com/mivan-formwork

[10]. http://www.mivan.com/modular/Mivan_Modular.pdf 